\title{
Good Work and Good Works: Work and the Postsecular in George Saunders's CivilWarLand in Bad Decline
}

Brian Jansen and Hollie Adams

\section{(2) OpenEdition Journals}

Electronic version

URL: https://journals.openedition.org/ejas/13191

DOI: 10.4000/ejas.13191

ISSN: 1991-9336

Publisher

European Association for American Studies

Electronic reference

Brian Jansen and Hollie Adams, "Good Work and Good Works: Work and the Postsecular in George Saunders's CivilWarLand in Bad Decline", European journal of American studies [Online], 13-2 | 2018,

Online since 19 July 2018, connection on 08 July 2021. URL: http://journals.openedition.org/ejas/ 13191 ; DOI: https://doi.org/10.4000/ejas.13191

This text was automatically generated on 8 July 2021.

Creative Commons License 


\title{
Good Work and Good Works: Work and the Postsecular in George Saunders's CivilWarLand in Bad Decline
}

\author{
Brian Jansen and Hollie Adams
}

Given his status as arguably the most critically celebrated practitioner of the short story today, it seems unusual the extent to which George Saunders's short fictions (particularly those of his earliest two collections, CivilWarLand in Bad Decline [1996] and Pastoralia [2000]) return, again and again, to the same thematic territory, the same motifs, even the same plots. A typical early George Saunders story, with variations, runs thusly: a down-on-his-luck narrator (usually male) in a vaguely dystopian American present slaves away at a cartoonish blue-collar job for little satisfaction and less financial reward. Said narrator, robbed of agency by the social conditions of his world, is forced to make some difficult choice, the act of which (and the outcome of which) leads invariably to an ethically compromised position. The jobs change-from historical theme park "verisimilitude inspector" ("CivilWarLand in Bad Decline") to professional caveman ("Pastoralia") to rodential pest exterminator ("The 400-Pound CEO"), "drive-through hand job" facilitator ("Bounty") to male stripper complete with oversized "Penile Stimulator" ("Sea Oak")-and the source of ethical compromise shifts, too, though the locust is often the protagonist's complicity in the death of another human being, usually a child, and often the hero is doubly compromised by the economic hardships of providing for a family (as the narrator of "CivilWarLand" reflects, "Is this the life I envisioned for myself? My God no. I wanted to be a high jumper. But I have two of the sweetest children ever born" [9]). As one representative review, published on the blog iog puts it, in Saunders's stories

personal humiliation is linked to cooperation in a morally bereft system. . . . [Saunders's characters] are people who participate in their own destruction, or who attempt to keep their heads above water even if that means pushing others 
underneath. The main constant, as always, is a sense of absurdity and its near neighbor, futility. (Anders)

2 And Saunders stories tend to end similarly, too, in a way that offers little practical resolution but lots of moralism. The wisdom of his work is often the same wisdom that he himself articulated in a now-widely anthologized 2013 Commencement Address, to "err in the direction of kindness" (qtd. in Lovell, emphasis in original)-a responsibility we have, both he and his stories suggest, even in a world that has robbed us of agency. ${ }^{1}$

Yet for all this sameness, for all this similarity, Saunders remains, as mentioned above, among the most celebrated American writers of our contemporary moment, and was long before the release of his debut novel Lincoln in the Bardo (2017) saw him feted in mainstream media news sources and on late night television, attaining a kind of literary celebrity arguably not seen since the likes of Norman Mailer or James Baldwin. ${ }^{2}$ Even before Bardo, Saunders had under his belt a MacArthur Fellowship (2006), four National Magazine Awards (1994, 1996, 2000, 2004), and a PEN/Malamud Award (2013), having also been a finalist for the PEN/Hemingway Award (1996), the O. Henry Award (1997), and the National Book Award (2013). He is, as another review puts it, "just about as famous and rhapsodized as an American fiction writer can get without triggering a [Jonathan] Franzenesque backlash" (Harvilla). And Saunders's commercial and critical success, we posit, might be read in part as prelude to what Kasia Boddy and others have observed as a return to "work" in American literature-a return, particularly in the wake of the recent American financial crisis, to thinking about class, money, and the exigencies of labour, whether manual or intellectual (2). ${ }^{3}$ Ralph Clare's monograph Fictions Inc. specifically notes a shift from "Cold War-era neuroses about political ideology to contemporary worries about economic power" (1), arguing particularly that the proliferation of corporate entities in contemporary literary texts speaks to "the vast and ungraspable enterprise of late capitalism" (3), attempting to "resist, reassess, and reimagine an economic system that, even after the ascent of the 'new economy,' is clearly failing" (4). To Saunders's version of corporate toil, Boddy adds works like Sam Lipsyte's The Ask (2010), David Foster Wallace's posthumous The Pale King (2011), ${ }^{4}$ and Joshua Ferris's Then We Came to the End (2007), and to this list we might in turn add myriad more. The turn to literatures of work has been crystallized, even, in university classes dedicated to the intersection of labour and the literary (such as Evergreen State College's "Odd Jobs and Labors of Love") and anthologies like Blue Collar, White Collar, No Collar: Stories of Work (2011), edited and introduced by Richard Ford.

4 Ford observes, in his introduction to Blue Collar, "that unless [he] could say ... what an important character did for a living, then that character didn't achieve the kind of persuasiveness [he] needed, the kind to make 'him' or 'her' 'real' . . . so that the character could carry moral weight, create consequence, transport the reader, be 'round"' (ix). Saunders has agreed, noting in an interview that "it's the dominant thing in American life. It's [something] almost all people do, and we do so much of it, too much of it maybe, and most always for someone else's improvement than our own. . . Most of us start working early and keep on working forever, and so I guess it would seem weird to me if work wasn't the dominant thing in my fiction" ("Between the Poles" 87). But, he goes on, "if you look at work, or write about work, and you are living in a capitalist society, then you are de facto looking at issues of sisterhood and brotherhood ... about the nature of our responsibilities towards one another" (87). In another interview, he notes something similar, that he "was never able to think of morality and a workplace separately because they were always impinging on one 
another" ("Crazy Elements"). Saunders's argument here echoes the language of Studs Terkel's oral history Working and the search it identifies "for daily meaning as well as daily bread, for recognition as well as cash, for astonishment rather than torpor; in short, for a sort of life rather than a Monday through Friday sort of dying" (xi). ${ }^{5}$

Work carries moral and ethical freight, a claim made clear by the slippage in its very definitions. The idea of work "as a means of making one's living or earning money" ( $n$., 4a) arises, according to the Oxford English Dictionary, roughly contemporaneously with the sense of "an act or deed expressive of a particular moral quality or purpose" (n., 1d) and "A good or moral act or deed considered in relation to justification before God" ( $n$., 1c). So too does the compound "good work," that is, "a morally commendable or virtuous act; an act of kindness, good will, or charity; esp. (in religious and theological contexts) an act of piety, regarded as carried out in obedience to the commandments, or as the product of faith or grace" ("good work," $n$.). At least one Saunders narrator is, indeed, aware of this slippage, distinguishing his 9-to-5 work from what he calls his "real job, [his] penance, [his] albatross" ("Offloading" 69)-that is, caring for an elderly neighbor.

6 It is with this link between "work" (in its various senses) and "good work" that we begin this line of thought, in tandem with an observation of a tendency toward religiosity (particularly Christian religiosity) in many of Saunders's short stories. That religiosity plays out in ways both sincere and parodic: on the one hand, many Saunders characters pray quite earnestly, while others offer religiously-grounded advice that the narratives seem to endorse (however tentatively). On the other hand, religious inclination is often rendered absurd, or heavily corporatized, from the "Center for Wayward Nuns" in "The Wavemaker Falters" to overpriced "Chill'n'Pray" coolers adorned with images of religious figures in "The 400-Pound CEO" (56), from Bibles filled with "fallacious pro-slavery sayings of Christ" ("Bounty" 178) to an employer who swears on a Bible that he'll "never hire a crazed maniac to perform an important security function again" ("CivilWarLand" 22). It is worth mentioning, too, that David Rando labels "Sea Oak's" Christian elements as the "theological grotesque" (452-53).

7 As much as Saunders seems drawn to Christian (particularly Catholic) religiosity, ${ }^{6}$ however, and as much as Saunders views the Catholic church as "in the world, on its feet and sort of activist" ("Real as Hell"), there is a hesitancy when it comes to the faith's precepts, perhaps traceable to what Saunders calls his interest in individual human "tendencies" rather than "systems" ("Between the Poles" 92). This interest in tendencies rather than systems perhaps explains the double-edgedness of his characters' relation with Christian faith: it is crucial to Saunders's critique of the power structures of post-industrial, late-capitalist life, and yet ultimately prone, in its institutionalized forms, to cooptation by those very same power structures. To wit, we offer the evangelical magazine Christianity Today's critique of what it calls Saunders's "misguided theology of kindness": "To make kindness into an ultimate virtue is to insist that our most important moral obligations are those we owe to our fellow human beings" (Pollock Michel), the article declares as though that were a bad thing, as though the First Commandment absolves Christians of any further obligations in the material world. That article posits instead that the most important commitment is not to one another but to the Christian God, an argument that the Ten Commandments must be read through the lens of what they take to be the First: "Do not put any other Gods in place of me" (Exodus 20:3, NIV). 
8 Rather than reading Saunders's fictions as straightforwardly (or even ambivalently) Christian, then, we want to pivot and engage Saunders as being a member of what John McClure, in Partial Faiths, identifies as a baby boomer "generation of seekers" who have sought to satisfy a relentless spirituality in evangelical teaching-but also mysticism, Eastern religion, Goddess worship, and New Age movements (8; Roof 4). For McClure, Saunders-a self-identified Tibetan Buddhist who has said that he doesn't "see Christianity and Buddhism as separate; in fact, ... one pick[s] up where the other left off" ("A Conversation With"), and who has suggested writing as a tertiary way of spiritual engagement ${ }^{7}$-certainly fits the mould of seekers who bring habits of "critical thinking and progressive political ideas" (8) to spiritualism, one of a group of "[r]eligiously unhoused but spiritually hungry . . . people increasingly negotiat[ing] among competing glimpses of the sacred, seeking partial knowledge and practical wisdom" (8). Religiously speaking, then, we want to position Saunders (through a close reading, particularly, of his short story "CivilWarLand in Bad Decline") in the tradition of literary postsecularism, that "mode of being and seeing that is at once critical of secular constructions of reality and dogmatic religiosity"-"tell[ing] stories about new forms of religiously inflected seeing and being" that are nevertheless "dramatically partial and open-ended" (McClure ix).

9 We acknowledge here that the risk of a "postsecular reading" is in the way (as has been argued by Fessenden, Coviello and Hickman, Hungerford, and others) it neatly cleaves categories. In the words of Zhange $\mathrm{Ni}$, the postsecular "implies that religion and the secular can be conceptualized as neatly bounded and easily separable entities, or even consecutive stages on an evolutionary ladder" (51). And, as Tracy Fessenden argues, " $[t] \mathrm{o}$ consider the career of secularization in American culture is ... also necessarily to consider the consolidation of a Protestant ideology that has grown more entrenched and controlling even as its manifestations have often become less visibly religious" (5) -that, in other words, the idea of secularity itself is deeply tied up in religious, particularly Protestant, contexts. Nevertheless, we view Saunders's fictions as consistent with what Mcclure identifies as the hallmarks of the postsecular literary tradition, its narratives

lead[ing] into zones where the characters must learn to reconcile important secular and religious intuitions and where they receive 'limited gift[s]' . . of the spirit. These characters are transformed and steadied, as it were, by the sense that the world is seamed with mystery and benignity, by awakened impulses to reverence, wonder, self-forgetfulness, and care, and by coming into company with others. These gifts make life more bearable, but they fall short of the gifts of absolute conviction or revival. (6)

10 Saunders's subjects and narrators are, quite often "strand[ed] . . in the ideologically mixed and confusing middle zones of the conventional conversion narrative" (Mcclure 4), his narratives again and again identifying "spiritualities [that] arise in the cracks of the social order, among the anonymous and the excluded" (McClure 20).

11 As McClure notes, in these sorts of texts, "other realms become visible but either partially and fleetingly or in bizarre superabundance" (4); the latter is certainly the case in the eponymous story of Saunders's debut collection, CivilWarLand in Bad Decline, which features an unnamed narrator in a dystopic present who labours at a Civil Warthemed amusement park and who must struggle amongst competing impulses: his hatred for his job, his commitment to his children, his desire to please his dissatisfied wife and the desire to do good, and the actual requirements of his job as Verisimilitude 
Inspector, which necessitates firing subordinates, hiring war criminals, and covering for said war criminals' bloody crimes. The narrator frequently imagines quitting but is stalled by "[his] last degrading batch of résumés. Two hundred send-outs and no nibbles.... [He] think[s] of his car payment" (4). He thinks of his children, Marcus and Howie, and how deeply they love a playhouse the narrator is still paying off. Elsewhere, he's reminded of the "droves of unemployed huddled in front of Personnel every morning" (18); positioned thusly as a kind of slave, the narrator struggles with his complicity in the war criminal, Samuel's, actions (namely disfiguring and murdering a teenager who has stolen some penny candy-the narrator is later forced to bury the teenager's dismembered hand). Metaphorically, the story thus enacts a tension not unlike that between the language of Colossians, and particularly St. Paul's advice to slaves: "Work at everything you do with all your heart. Work as if you were working for the Lord, not for human masters. Work because you know that you will finally receive as a reward what the Lord wants you to have" (23-24, NIV), and the language of Corinthians: "Each one of us will be judged for what we do while in our bodies" (2 Cor 5:10, NIV).

Complicating the narrative are the myriad ghosts inhabiting the world of CivilWarLand, particularly the McKinnons (1860s homesteaders who lived and died on the land now occupied by the theme park) and-later-the ghost of the teenage thief whose hand the narrator has buried. These figures appear, in the language of McClure, "with the vulgar exuberance of a tabloid headline" (17), but their presence is difficult to explain. Though the narrator speculates that they wander the grounds because "something must have happened to them" (12), and it is ultimately revealed that the family is restless-afterdeath because they were murdered by Mr. McKinnon in a fit of what we might diagnose today as PTSD-induced rage (24-25), it is not quite clear, for instance, who can and cannot see the McKinnons (or why). They are, again via McClure, "visitations suggest[ing] that the laws of nature may be contingent," but they do not provide any clearly demarcated alternative to those laws of nature (4), a point further emphasized by the fact that the narrator speculates he will be sent to the "nut-hut" (20) if he admits to seeing the McKinnons, and the fact that the story's various ghosts seem to operate differently in terms of their knowledge. As the narrator points out, the McKinnons seem largely unaware of their ghostly status-“they don't realize we're chronologically slumming, they just think the valley's prospering" (12)-whereas the slain teenager and the narrator himself (in death) seem to possess deeper insight, what the narrator himself calls "perfect knowledge" (26) of both the past and future. And what's remarkable about the McKinnons, in particular, is the fact that despite their incomplete knowledge and their fundamentally flawed nature (they are certainly not god-like), their diagnoses of the narrator are astute: it is not technically true, as Mr. McKinnon observes, that a fire in the park is "divine retribution for [the narrator's] slovenly moral state" (13), but metaphorically it may be so (and it is, moreover, prophetic of another fire soon to come later in the narrative). Similarly, Mr. McKinnon's observation that "even the heavens have fallen into disrepair" (13) has a kind of metaphorical truth value (even as the narrator ironically notes that he is resisting the urge to explain smog to the ghost), recalling Saunders's own observations about the power of metaphor and symbol in his Catholic childhood ("Real as Hell"; "A Conversation"). ${ }^{8}$

Mr. McKinnon's ghostly metaphorical insight extends, too, to his status as literary parallel-both to the narrator and the mercenary amusement park employee Samuel. 
The former connection is made explicit in the text: after the McKinnons wander too close to the site of their deaths and begin-compelled by something beyond explanation-to act out their deaths over-and-over ("the Mr." mimes hacking them to death with a scythe [24]), Mr. McKinnon finally "sits down in the dirt and starts weeping" (25), seeking to "pitifully ... explain" his behaviour in much the same way as the narrator has to his interlocutor. As the family breaks the cycle of these reenactments and departs down the hill, Mr. McKinnon follows, "shouting for forgiveness. He's shouting that he's just a man. He's shouting that hatred and war made him nuts" (25). Tellingly, the narrator follows, echoing Mr. McKinnon's pleas: "I start running down the hill agreeing with him" (25). Thus the narrator seeks forgiveness from a world beyond his own, but he is doing so to those who can offer no such forgiveness, and he is nevertheless wrenched back into the profane, material world, reminded of his corporeal status by the fact that he-unlike the McKinnons, who simply pass through obstacles-"keep[s] clipping trees with [his] shoulders and falling down" (25).

14 But in his resemblance also to the mercenary Samuel, Mr. McKinnon actually links the three characters as inextricable, a kind of tripartite (an unholy trinity), McKinnon's service in the Civil War (he was at Antietam [13]) a distant historical echo of Samuel's military service: Samuel was "kicked out of Vietnam for participating in a bloodbath" [14]). Where the story could play Samuel as villain, however, he too is humanized, the narrator coming only in death to understand the source of Samuel's pain, even as the narrator (and the story more generally) refuses to use that pain as justification or excuse: "I see his rough childhood. I see his mother doing something horrid to him with a broomstick. I see the hate in his heart and the people he has yet to kill before pneumonia gets him at eighty-three" (26). The reader is perhaps meant to note the unfairness of this fate, that an unrepentant murderer should die relatively peacefully in old age, but of course the broader point may be the fact that life being unfair-even random-does not absolve us of our responsibilities to one another, moment-tomoment.

"CivilWarLand" concludes with the narrator's ethical quandary coming to a head, confronted by the ghost of the teen whose hand he has buried before he is, in turn, murdered by the war criminal who killed the teen in the first place. Samuel has to cover his tracks, and his reassurances, "Don't take this too personal" (26), might be read in light of the narrator's unwillingness to take things "personal," his detachment from his potentially harmful actions. Previous to this moment, the narrator debates the virtue of his actions repeatedly, invoking both religious and legal precedent-"It doesn't say anywhere thou shalt not bury some guy's hand," he claims, before admitting that legally he is "an accomplice and obstructor of justice" (20). But his ultimate, flaccid defense to the disfigured teenage ghost, that the mercenary Samuel "wasn't my friend" (25) is not enough, for “[h]e wasn't [the narrator's] enemy" (25), either (impersonality, in other words, might be part of the problem), and the ghost makes clear that the narrator must live because he has "amends to make" (25). The implication here is that said amends cannot be made in the/an afterlife: the story explicitly rejects the narrator's earlier decision, fearing for the well-being of his boys, that he will "take [his] lumps in the afterlife" (20). The narrator's subsequent death at the hands of Samuel makes this point heartbreakingly clear, as the (now himself ghostly) narrator seeks futilely to correct the wrongs he has done-he "sweep[s] through Sam's body, trying to change him, trying so hard, and feeling only hate and 
hate, solid as stone" (26). The lesson is that it is not what happens after death that counts but what we do in our lives: we are, returning to Corinthians "judged for what we do while in our bodies" (2 Cor 5:10, NIV), and it is telling the sheer simplicity of the wish the narrator dies with, that he had loved his wife better, in spite of her flaws. The narrator's failure is a failure-to return to Saunders's oft-stated non-fictional thesis-of kindness, a failure of empathy on both a local and a grand stage. As Layne Neeper has argued in his account of Saunders's satirical dimension, a story like "CivilWarLand in Bad Decline" "identifies vice and folly with withering exactitude; [Saunders] does so in wildly imaginative and dramatic fictional worlds, but, rather than stories ending with the emergence of some amorphous sense of correction, Saunders's stories intend only one development: the empathetic improvement of his audience" (284-85).

In his emphasis on this brand of kindness, Boddy identifies Saunders's work, via Rachel Greenwald Smith, as a kind of "neoliberal fiction." Boddy argues that Saunders's own religious impulse to connect "inner and outer work" (10) and his sense that "we must change ourselves in order to change the world" (Kraft, qtd. in Boddy 10) might also be read through the neoliberal suggestion that "attachments beyond the self" can offer some chance at "self-development" (Smith, qtd. in Boddy 10). Boddy is critical, for example, of the way that Saunders's work embodies principles of self-betterment/selfculture even as it mocks the conventions of the traditional self-help genre; she is critical, too, of Saunders's aforementioned emphasis on "tendencies" rather than "systems" (Saunders, "Between the Poles" 92) and his keenness on "remain[ing] permanently confused" (Saunders, qtd. in Boddy 10)-his refusal to see corporations, government, and media as actively hostile, exploitive oppressors rather than simply as manifestations of qualities existing in all of us.

There is, we think, some merit in this critique. Though Saunders has spoken of his sense that "Christianity did a lot of urging one to be good but didn't tell one much about how to accomplish that" while Buddhism "offered real practices that a person could do every day" "to change ... to convert one's way of thinking and being in the world" ("A Conversation"), these real practices do not seem to appear often in Saunders's short stories, which tend instead toward that aforementioned generalizable character of simple kindness. As Neeper has pointed out, "any reader who approaches [Saunders's stories] will be hard-pressed to identify, let alone name, any proposed normative correction, or what cautions are intended or even possible" (285), at least beyond "a new or renewed attentiveness to unironic empathy" (285).

But, even bypassing Saunders's claims that his stated aim is the "erasure of self and acceptance of the conditionality of all things" ("A Conversation"), Boddy's criticism nevertheless strikes us as somewhat ungenerous. If, as the old saw (variously attributed to Fredric Jameson and Slavoj Žižek) goes, "it is easier to imagine the end of the world than it is to imagine the end of capitalism" (Fisher 2)-and, as some of Saunders's dystopic stories, particularly "Bounty" suggest, even the apparent end-of-the-world as we know it fails to lend us such a glimpse-then it does not seem constructive to castigate an author for not having all the answers. This is particularly true given that Saunders's stories seek to guide readers, at the very least, away from an alternative, almost certainly more unhelpful reaction to the state of the world: a radical, ascetic interiority embodied in Saunders's depiction (in "Bounty") of the "Church of Appropriate Humility" (122). The "Guilters" (122), as they are colloquially called, are a radical sect that believes in quantifying pain (measured in units called Victors, with 
each Victor seen as a step toward salvation), its members utterly lost in semantic debates about what does and does not merit these pain points-misdirecting someone seeking directions, for example, merits Victors "[i]f you feel really bad about it, to the point where you can't sleep" (123). But "[o]n the other hand . . . if you're now experiencing any pleasure thinking of your future Victors, that could mean you have to apply anti-Victors to your running total" (123). The same unhelpful, inward turn is found in "CivilWarLand," in the tertiary character Melvin (proprietor of Melvin's Pasta Lair), whose religious zealotry (his advice to simply "stop whining and count [your] blessings" [23], his castigation that men are "incapable of coping with life without the intervention of God the Almighty" [23]) is both wildly unhelpful for the situation-athand and leads him to scorch the pizza he is preparing. The problem occurs, too, in "The Wavemaker Falters," which opens with the "Center for Wayward Nuns, full of sisters and other religious personnel who've become doubtful" (34). The Center's nuns (whose "conditional singing" "never exactly knocks your socks off. . . probably because of all the doubt" [34]) are given free passes to the waterpark where the narrator labours. The pass appears to help one such nun, Sister Viv (the stream seems to have reminded her of her Idaho roots, her embodied existence in this world rather than her commitments to a world beyond she has come to doubt), until she attempts suicide and is rescued by the narrator (himself dealing with the guilt of having killed a child on the job), at which point a revealing conversation takes place-two characters struggling with the same kind of doubt and pain but addressing it differently: "she ... spits in my face and says I couldn't possibly know the darkness of her heart. Try me, I say" (35). In classic Saunders fashion, of course, the narrator is punished for having saved Sister Viv - "[a] week later she runs amok in the nun eating hall and stabs a cafeteria worker to death" (35)-though Saunders's stories disavow the consequentialist argument that outcome determines the worth of an action. ${ }^{9}$

We conclude by observing that Saunders's approach to the problems of our capitalist society, however provisional, ${ }^{10}$ nevertheless echoes the thesis of Mark Fisher's slim volume Capitalist Realism, particularly the observation that "people suffer from . . . being trapped within themselves" (Curtis, qtd. in Fisher 74) as well as Fisher's call for "a new struggle over work and who controls it; an assertion of worker autonomy (as opposed to control by management) together with a rejection of certain kinds of labor (such as the excessive auditing which has become [a] so central feature of work)" (79). The work in Saunders's works-the slippage between definitions of what work meansgestures, in some small way, to what Fisher discusses. Saunders's short stories are only one voice, calling readers out of themselves, tentatively so-perhaps because that is the nature of partial faiths-but, as Fisher argues, "even glimmers of alternative possibilities ... can have a disproportionately great effect" (80). Or, in Saunders's own words, you "take ... baby steps" ("A Conversation"). A short story, a poem, or a novel may not singlehandedly defeat evil, but-as Saunders has written, his phrasing loaded with same generalizable yet essential spiritual freight-"what good the prophet in the wilderness may do is incremental and personal. It's good for us to hear someone speak the irrational truth" ("Mr. Vonnegut" 82). There is, he adds, "something sacred" about a good literary work, "even if nothing changes but what's going on inside our minds. We leave such a book restored, if only briefly, to a proper relation with the truth, reminded of what is what, temporarily undeluded, our better nature set back on its feet" (83). 
It remains to be seen, in the final analysis, whether Saunders's semi-spiritual vision for literature offers a way out of the problems of our capitalist moment, or whether that spirituality is only a secondary symptom of that same moment, trapping the author himself in the logic of neoliberalism and dooming him to the same fate-ethical compromise, guilt, repentance, repeat-as so many of his characters. ${ }^{11}$ But for Saunders, at least, if not for his critics, the link between literature's spiritual freight and the possibility for action is evidenced by one of the few directly prescriptive moments in Saunders's oeuvre-the unpublished Seussian poem "Trump L'Oeil," posted to his Facebook account in February 2017, in which Saunders not-so-subtly ties imagination and direct action. "[G]oodness, peace, and decency / Were never heavensent" (65-66), the poem acknowledges, while still recognizing the power of that aforementioned "irrational truth." He writes: "Speak out, rise up, correct and shout, / Be stubborn and satirical" (57), before going on, specifically calling on his readers to be not just but "positive" but "lyrical" (60).

\section{BIBLIOGRAPHY}

Anders, Charlie Jane. “George Saunders' New Book Shows Just How Terrible First World Problems Can Be.” io9, 5 February 2013, io9.gizmodo.com/5981861/george-saunders-new-book-shows-justhow-terrible-first-world-problems-can-be. Accessed 30 May 2017.

Blakeslee, Steve and Sarah Ryan. "Odd Jobs and Labors of Love: Literature, Work, and Power." Evergreen State College, 2018, www.evergreen.edu/catalog/offering/odd-jobs-and-labors-loveliterature-work-and-power-16357. Accessed 19 June 2018.

Boddy, Kasia. “'A Job to Do': George Saunders on, and at, Work.” George Saunders: Critical Essays, edited by Philip Coleman and Steve Gronert Ellerhoff, Palgrave Macmillan, 2017, pp. 1-22.

Bowe, John, Marisa Bowe and Sabin Streeter, editors. Gig: Americans Talk About Their Jobs. Three Rivers, 2001.

Christian, Scott. “The Novel is Dead, Long Live the Chipotle Cup.” GQ, 15 May 2014, www.gq.com/ story/jonathan-safran-foer-chipotle-cup-stories. Accessed 2 June 2017.

Clare, Ralph. Fictions, Inc.: The Corporation in Postmodern Fiction, Film, and Popular Culture. Rutgers UP, 2014.

Coviello, Peter and Jared Hickman. "Introduction: After the Postsecular." American Literature, vol. 86, no. 4, 2014, pp. 645-54.

Dorson, James. "The Neoliberal Machine in the Bureaucratic Garden: Pastoral States of Mind in David Foster Wallace's The Pale King." Rereading the Machine in the Garden: Nature and Technology in American Culture, edited by E. Erbacher, N. Marus-Schroder, F. Sedlmeier, Campus Verlag, 2014, pp. 211-30.

Felch, Susan M. "Ethics." The Cambridge Companion to Literature and Religion, edited by Susan M. Felch, Cambridge UP, 2016, pp. 71-83. 
---. "Introduction." The Cambridge Companion to Literature and Religion, edited by Susan M. Felch, Cambridge UP, 2016, pp. 1-17.

Ferris, Joshua. “Nine to Five.” The Guardian, 21 April 2007, www.theguardian.com/books/2007/ apr/21/featuresreviews.guardianreview2. Accessed 19 June 2018.

---. Then We Came to the End. Little, Brown, 2007.

Fessenden, Tracy. “The Problem of the Postsecular.” American Literary History, vol. 26, no. 1, 2014, pp.154-67.

Ford, Richard. "Introduction." Blue Collar, White Collar, No Collar: Stories of Work, edited by Richard Ford, Harper Perennial, 2011, pp. vii-xiv.

"George Saunders: The Photocopier Guy Makes Good." The Independent, 10 June 2006, www.independent.co.uk/arts-entertainment/books/features/george-saunders-the-photocopierguy-makes-good-6098574.html. Accessed 1 June 2017.

“Good work." Oxford English Dictionary. 3rd ed., 2004.

Greenwald Smith, Rachel. Affect and American Literature in the Age of Neoliberalism. Cambridge UP, 2015.

Harvilla, Rob. “The Cold Comfort of George Saunders.” The Ringer. 14 Feb 2017, theringer.com/ george-saunders-lincoln-in-the-bardo-75c7d40de784. Accessed 1 June 2017.

Hayes-Brady, Clare. The Unspeakable Failures of David Foster Wallace: Language, Identity, and Resistance. Bloomsbury, 2016.

Hungerford, Amy. Postmodern Belief: American Literature and Religion Since 1960. Princeton UP, 2010.

Hutchens, B. C. Levinas: A Guide for the Perplexed. Continuum, 2004.

Jackson, Edward and Joel Nicholson-Roberts. "White Guys: Questioning Infinite Jest's New Sincerity." Orbit, vol. 5, no. 1, 2017, DOI: http://doi.org/10.16995/orbit.182

Jansen, Brian. “The Fiction Factory: A Novel.” Dissertation, University of Calgary, 2018.

Kelly, Adam. "David Foster Wallace and the New Sincerity in American Fiction." Consider David Foster Wallace: Critical Essays, edited by David Haring, Sideshow, 2010, pp. 131-46.

Lipsyte, Sam. The Ask. FSG, 2010.

Lovell, Joel. “George Saunders's Advice to Graduates.” New York Times, 3 July 2013, 6thfloor.blogs.nytimes.com/2013/07/31/george-saunderss-advice-to-graduates/. Accessed 30 May 2017.

Mason, Tom and Sarah Klein. "George Saunders Explains How to Tell a Good Story.” The Atlantic, 8 Dec 2015, www.theatlantic.com/video/index/419391/george-saunders-on-story/. Accessed 1 June 2017.

“A Master at Work: George Saunders Orders One Mousetrap Over the Phone." ClickHole, 26 April 2017, www.clickhole.com/video/master-work-george-saunders-orders-one-mousetrap-o-5970. Accessed 31 May 2017.

McClure, John A. Partial Faiths: Postsecular Fiction in the Age of Pynchon and Morrison. U of George P, 2007.

McMahon, Julie. “SU Professor George Saunders ‘Quite Possibly’ Stephen Colbert's Favorite Living Author." Syracuse.com. 16 Feb 2017, www.syracuse.com/schools/index.ssf/2017/02/ 
su_professor_george_saunders_quite_possibly_stephen_colberts_favorite_living_aut.html. Accessed 31 May 2017.

Miller, Laura. "The Beautiful World." Review of Lincoln in the Bardo, by George Saunders, Slate, 6 Feb 2017, www.slate.com/articles/arts/books/2017/02/ george_saunders_lincoln_in_the_bardo_reviewed.html. Accessed 1 June 2017.

Neeper, Layne. “'To Soften the Heart': George Saunders, Postmodern Satire, and Empathy." Studies in American Humor, ser. 4, vol. 2, no. 2, 2016, pp. 280-99.

Ni, Zhange. "Postsecular Reading." The Cambridge Companion to Literature and Religion, edited by Susan M. Felch, Cambridge UP, 2016, pp. 51-67.

Pogell, Sarah. “'The Verisimilitude Inspector': George Saunders as the New Baudrillard.” Critique: Studies in Contemporary Fiction, vol. 52, no. 4, 2011, pp. 460-78.

Pollock Michel, Jen. “The Misguided Theology of Kindness.” Christianity Today, August 2013, www.christianitytoday.com/women/2013/august/misguided-theology-of-kindness.html. Accessed 29 May 2017.

Potts, Matthew. "Imagination." The Cambridge Companion to Literature and Religion, edited by Susan M. Felch, Cambridge UP, 2016, pp. 103-115.

Rando, David P. “George Saunders and the Postmodern Working Class.” Contemporary Literature, vol. 53, no. 3, 2012, 437-460.

Roof, Wade. A Generation of Seekers: The Spiritual Journeys of the Baby Boom Generation. HarperCollins, 1993.

Saunders, George. “The 400-Pound CEO.” 1996. Riverhead, 1997, pp. 45-64.

---. "Between the Poles of Biting \& Earnest." Interview with Derby. Columbia: A Journal of Literature and Art, no. 35, 2001, pp. 87-99.

---. “Bounty." CivilWarLand in Bad Decline. 1996. Riverhead, 1997, pp. 88-197.

---. “CivilWarLand in Bad Decline.” CivilWarLand in Bad Decline. 1996. Riverhead, 1997, pp.3-26.

---. “A Conversation with George Saunders." Interview with W. Brett Wiley. Image, no. 88, n.d., imagejournal.org/article/a-conversation-with-george-saunders/. Accessed 21 May 2017.

---. “The Crazy Elements: PW Talks with George Saunders." Interview with J. W. McCormack. Publishers Weekly, vol. 259, no. 46, 2012, p. 39.

---. “George Saunders's Humor.” Interview with Mike Sacks. The New Yorker, 19 June 2014, www.newyorker.com/books/page-turner/george-saunderss-humor. Accessed 29 April 2017.

---. Lincoln in the Bardo. Random House, 2017.

---. “Mr. Vonnegut in Sumatra.” The Braindead Megaphone. Riverhead, 2007, pp. 73-83.

---. “Offloading for Mrs. Schwartz.” 1996. Riverhead, 1997, pp. 65-77.

---. "Pastoralia." Pastoralia. Riverhead, 2000, pp. 1-68.

---. "Real As Hell: A Conversation with George Saunders." Interview with Maria Bustillos. The Awl, 19 Feb 2013, theawl.com/real-as-hell-a-conversation-with-george-saunders-83970facba09. Accessed 29 April 2017.

---. “Sea Oak." Pastoralia. Riverhead, 2000, pp. 91-126. 
---. “Trump L'Oeil.” Facebook, 20 February 2017, www.facebook.com/GeorgeSaundersFans/posts/ 1254664397974281 . Accessed 18 June 2018.

---. “The Wavemaker Falters." CivilWarLand in Bad Decline. 1996. Riverhead, 1997, pp. 34-44.

---. "George Saunders: What Writers Really Do When They Write.” The Guardian, 4 March 2017, www.theguardian.com/books/2017/mar/04/what-writers-really-do-when-they-write. Accessed 2 June 2017.

Terkel, Studs. Working. 1972. The New Press, 2004.

Wallace, David Foster. The Pale King. Little Brown, 2011.

Williams, Iain. “(New) Sincerity in David Foster Wallace's 'Octet'." Critique: Studies in Contemporary Fiction, vol. 56, no. 3, 2015, pp. 299-314.

"Work." Oxford English Dictionary. 3rd ed., 2004.

\section{NOTES}

1. By way of this call to kindness, Saunders has often been identified as a practitioner of the socalled "New Sincerity" (a contested, often-maligned term [see Jackson and Nicholson-Roberts; Dorson; Williams; Hayes-Brady]) alongside figures like Michael Chabon, David Foster Wallace, and Dave Eggers. Coined by critic Adam Kelly to describe writers and texts that "place . . emphasis on intersubjective truth and communication with others" (132), the classification emerges from the phrase's appearance in a 1993 essay by David Foster Wallace. For more on Saunders and the New Sincerity, see Pogell (478) and especially Neeper.

2. Saunders made appearances on The Late Show with Stephen Colbert (where Colbert called him "quite possibly my favorite living author" [qtd. in McMahon]) and Late Night with Seth Meyers. But perhaps his most brilliant promotional appearance was for ClickHole, sister site of the satirical news source The Onion, which mocks the conventions of clickbait content on the web. In his appearance, titled "A Master At Work," Saunders is filmed attempting to order a single mousetrap by telephone.

3. Ferris in particular distinguishes between "way-of-life" work (as in Marlow's trip down an African river, Quixote's knight-errantry) and "means-to-end" work-the programmer, the project manager ("Nine to Five").

4. Milo Burke, the hero of Lipsyte's novel, actually works as a development officer (read: fundraiser) for a bottom-tier university, but the novel speaks to the contemporary corporatization of even the academic environment (see Jansen 25-27). Wallace's novel, set predominately in an Internal Revenue Agency auditing centre, could be read as enacting the same sort of critique of government.

5. Another oral history, Gig: Americans Talk About Their Jobs, updates these anxieties for the twenty-first century: "work is key to your existential circumstances," its introduction declares: "Who am I? What do I want? What is my place in the world and my status within it? Am I useful? Am I fulfilled?" (Bowe xiii).

6. In various interviews he reports that he "loved growing up Catholic," had "a couple of really deep experiences in church," and characterizes the Stations of the Cross as a "profound ... fictive exercise" ("Real as Hell").

7. Interviewed in the Independent, Saunders observes that he "felt like [he] was a Buddhist before [he] knew it, because writing. ... Well, what else is it? You put something down on Thursday, and if you get attached to the idea of how good it was on Thursday, then on Friday you're screwed" (qtd. in "Photocopier Guy"). Interestingly, many of Saunders's best-known public comments (see 
Mason and Klein; Saunders, "What Writers Really Do") have focussed on the sentence-bysentence craft and work of writing as much or more than its moral or ethical dimension-but these very comments suggest the extent to which a story's craft and a story's purpose are intertwined. See Boddy (11-14) for a discussion of work in the context of Saunders's craft and the MFA model of creative writing.

8. As discussion around his novel Lincoln in the Bardo (2017) suggests, Saunders's ghosts across his oeuvre owe a debt to the Tibetan Buddhist concept of the bardo, a "way station between incarnations in which souls prepare themselves for their next life" (Miller). In that novel, the "ghosts" that haunt a Washington, D.C. cemetery find themselves in this liminal space due to unfinished business of one kind or another. Interestingly, however, for the purpose of our argument, Laura Miller's review of Lincoln argues that while "[t]he novel's title, and the role of attachment in detaining the spirits in their limbolike semi-existence, suggests an underlying Buddhist cosmology[,] . . . one of the ghosts, a former reverend, claims to have glimpsed beyond this world a place of terrible judgment and punishment." Miller speculates, then, that "it's possible that Saunders means the afterlife to be a reflection of whatever the individual soul expects to see."

9. It is beyond the scope of this particular essay, but Saunders's remarks regarding the self-his personal belief that we ought to strive for a Christ- or Buddha-like "unconditional love and erasure of the self" ("A Conversation With") might actually position him outside of any sort of normative ethics, either consequentialist or deontological. Rather, there is something almost Levinasian about this stance, supposing as it does that " $t]$ he relation between a self and another person is the basic context in which ethical problems must be examined" (Hutchens 8).

10. Saunders is, after all, no radical: he self describes as an "Eastern liberal" (qtd. in Boddy 11) and has had his work "published" on drinking cups at the Mexican restaurant chain Chipotle (Christian).

11. The authors are grateful to the European Journal of American Studies' peer reviewer for articulating this tension so eloquently.

\section{ABSTRACTS}

Drawing on what American short story writer and novelist George Saunders has described as the urge toward kindness in his work, as well as its myriad allusions to Christian symbology and religiosity, this paper explores the intersection of languages of labour or "work" and religious tensions in Saunders' oeuvre. Reading the stories of Saunders's first collection, CivilWarLand in Bad Decline, through the lens of postsecular literary theory and Saunders's own comments on Catholicism, we suggest that Christianity, for Saunders, is a double-edged sword: crucial to his social critique of the power structures of post-industrial, postmodern life, and yet ultimately prone, in its institutionalized forms, to cooptation by those very same power structures. Saunders's "Center for Wayward Nuns" is a potent metaphor in the sense that it suggests that doubt and lack of agency endemic to a fragmented postmodern world do not absolve us of our ethical responsibility, and thus the Christian overtones of Saunders' work are engaged in a compelling kind of double-critique: both of the "un-Christian" social realities of the world in which Saunders' working poor toil, but also of the kind of extremist, fundamentalist-even corporatized-Christianity that may emerge out of those social realities. 
INDEX

Keywords: George Saunders, John McClure, postsecular, Christianity, CivilWarLand in Bad Decline, American literature, work

\section{AUTHORS}

\section{BRIAN JANSEN}

Brian Jansen teaches Media Studies and Professional Communications at Red Deer College in Alberta, Canada. His work in American literatures and cultures has appeared most recently in The Journal of Popular Culture, the Journal of the Short Story in English, and ESC: English Studies in Canada.

\section{HOLLIE ADAMS}

Hollie Adams teaches Composition and Literature at Red Deer College in Red Deer, Alberta. She writes and researches in the fields of American Literature, Children's Literature, and Narratology. 